\title{
Pemetaan Penyakit Pneumonia di Provinsi Jawa Timur
}

\author{
Sulis Susanti \\ Departemen Biostatistika dan Kependudukan FKM UNAIR \\ Fakultas Kesehatan Masyarakat Universitas Airlangga \\ Kampus C Unair Mulyorejo Surabaya 60115 \\ Alamat Korespondensi: \\ Sulis Susanti, Sulisakun@gmail.com
}

\begin{abstract}
Morbidity and mortality in infants can be caused by various reasons one of which is pneumonia. UNICEF reported that 21,000 children under five in Indonesia died due to pneumonia in 2012. East Java one of the provinces with the high level of infant pneumonia. Recording and reporting the results of the year 2012 the number of sufferers reported by Regency/City is 84.392 people. The purpose of this study was to describe how the distribution and causes of pneumonia cases in the province of East Java using geoda program. The sample used in this study is the total of the population that is 38 district/city in East Java province. The variables studied were immunized against measles, vitamin A, a clean and healthy life behavior (PHBS), poor nutrition. The results of this study show that the coverage of measles immunization lowest in 5 districts and 4 cities, vitamin A is lowest in 8 districts and 1 city, 1 PHBS lowest in the city and 7 districts, malnutrition was highest in 7 districts and 4 Cities. In accordance with the results of the study are expected counseling about the cause of pneumonia can be scaled according to the conditions of the region, especially the parents.
\end{abstract}

Keywords: pneumonia, spatial analysis, toddlers

\begin{abstract}
ABSTRAK
Morbiditas dan mortalitas pada balita dapat disebabkan oleh berbagai sebab salah satu diantaranya yaitu penyakit pneumonia. UNICEF melaporkan bahwa 21.000 balita di Indonesia meninggal yang disebabkan karena pneumonia pada tahun 2012. Jawa Timur merupakan salah satu Provinsi dengan tingkat pneumonia balita yang tinggi. Hasil pencatatan dan pelaporan tahun 2012 jumlah penderita yang dilaporkan oleh Kabupaten/Kota adalah 84,392 orang. Tujuan penelitian ini adalah untuk mendeskripsikan bagaimana sebaran kasus dan penyebab pneumonia di Provinsi Jawa Timur dengan menggunakan program geoda. Sampel yang digunakan dalam penelitian ini adalah total dari populasi yaitu 38 Kabupaten/Kota yang ada di Provinsi Jawa Timur. Variabel yang diteliti yaitu imunisasi campak, vitamin A, Perilaku hidup bersih dan sehat (PHBS), gizi buruk. Hasil dari penelitian ini menunjukkan bahwa cakupan imunisasi campak terendah terdapat di 5 Kabupaten dan 4 Kota, vitamin A terendah ada di 8 Kabupaten dan 1 Kota, PHBS terendah ada di 1 Kota dan 7 Kabupaten, gizi buruk terbanyak di 7 kabupaten dan 4 Kota. Sesuai dengan hasil penelitian diharapkan penyuluhan tentang penyebab pneumonia dapat ditingkatkan sesuai kondisi wilayah tersebut terutama orang tua.
\end{abstract}

Kata kunci: pneumonia, analisis spasial, balita

\section{PENDAHULUAN}

Perkembangan ilmu pengetahuan dan teknologi, untuk membantu mendukung pengambilan keputusan terhadap munculnya Kejadian Luar Biasa (KLB) maka dapat dibuat dengan menggunakan aplikasi SIG sebagai bentuk perencanaan.

Keunikan karakteristik dan fenomena suatu wilayah seringkali kurang teramati. Informasi tentang karakteristik lokasi dapat dijelaskan dengan menggunakan analisis data spasial.
Data spasial merupakan data hasil pengukuran yang memuat informasi lokasi (geografis) setiap bagian data selain menggambarkan Fenomena juga dapat memberikan sebaran dari fenomena dalam satu wilayah. Pengamatan data spasial di suatu wilayah tergantung pada pengamatan di lokasi lain. Data spasial merupakan salah satu data independen karena dikumpulkan dari lokasi spasial yang berbeda dan menunjukkan adanya ketergantungan antara data dan lokasi. (Handayani, 2013). 
Kejadian penyakit merupakan fenomena spasial yang pada dasarnya adalah proses yang terjadi di atas muka bumi sejak ribuan tahun lalu. Satu kejadian penyakit dipengaruhi oleh berbagai faktor ruang yang antara lain meliputi ketinggian permukaan tanah, jenis tanah, iklim, suhu, tanaman sekitar, kepadatan dan perilaku penduduk, bentuk rumah, budaya, arah dan kecepatan angin dan sebagainya (Achmadi, 2009).

Anak-anak terutama pada usia balita merupakan usia yang rawan pada masalah gizi dan penyakit infeksi salah satu di antaranya yaitu pneumonia. Pneumonia juga sebagai salah satu penyakit infeksi pada usia lanjut, dan masih merupakan problem kesehatan masyarakat karena tingginya angka kematian disebabkan penyakit tersebut di berbagai negara termasuk Indonesia (Misnadiarly, 2008).

Hasil Riset Kesehatan Dasar (Riskesdas) tahun 2007, menunjukkan morbiditas pneumonia pada Bayi: $2.2 \%$, dan pada balita: $3 \%$, sedangkan mortalitas pada bayi $23,8 \%$, dan balita $15,5 \%$ (Depkes RI, 2011). Kematian pneumonia yang terbesar ditemukan pada bayi berumur kurang dari 2 bulan (Depkes RI, 2010).

Pneumonia selalu berada dalam daftar 10 penyakit terbanyak di rumah sakit sentinel dan puskesmas sentinel di Jawa Timur mulai tahun 2008 hingga 2010. Sedangkan berdasarkan laporan Kabupaten/Kota di Jawa Timur, kasus oneumonia pada balita tahun 2010 mencapai 76.745 kasus. Sehingga dapat disimpulkan bahwa penyakit pneumonia masih menjadi masalah kesehatan yang cukup besar di Provinsi Jawa Timur.

Jawa Timur merupakan salah satu Provinsi dengan tingkat pneumonia balita yang tinggi. Hasil pencatatan dan pelaporan tahun 2012 jumlah penderita yang dilaporkan oleh Kabupaten/Kota adalah 84,392 orang. Kasus pneumonia yang terjadi banyak tidak terlaporkan, dari banyak kasus yang ada kasus yang tercatat kurang lebih hanya $80 \%$. Pendekatan spasial sangat bermanfaat untuk mengetahui bagaimana penyebaran suatu penyakit, terutama penyakit menular yang sangat dipengaruhi oleh lingkungan sekitarnya. Suatu daerah yang saling berdekatan akan lebih berisiko tertular dibandingkan daerah yang letaknya berjauhan.
Informasi mengenai tataletak suatu daerah dan pola penyebaran penyakit akan lebih terlihat bila menggunakan pendekatan spasial. Sehingga data tentang suatu penyakit akan lebih terpantau, bukan hanya siapa yang sakit tetapi juga bagaimana letak geografi antar suatu daerah dengan kasus yang terjadi.

\section{METODE PENELITIAN}

Penelitian ini menggunakan, data yang berasal dari Laporan Eksekutif Kesehatan Provinsi Jawa Timur 2012 (Profil Kesehatan Provinsi Jawa Timur tahun 2012). Pada penelitian ini variabel yang digunakan yaitu pneumonia pada balita. imunisasi campak, vitamin A, perilaku hidup bersih dan sehat (PHBS), dan status gizi buruk.

Analisis pada penelitian ini deskriptif. Analisis statistic secara deskriptif yaitu analisis yang dilakukan dengan cara mendeskripsikan hasil sebaran variabel independen yang berhubungan dengan pneumonia pada balita pada peta kuantil tematik.

Kuantil yang tersaji dalam peta tematik terdiri dari 4 (empat) kuantil dengan kuantil pertama adalah kuantil dengan jumlah kasus terbanyak, dan kuantil ke empat yaitu kuantil dengan jumlah kasus paling sedikit di wilayah tersebut.

\section{HASIL PENELITIAN}

Jawa Timur adalah sebuah provinsi di bagian timur Pulau Jawa. Hasil dari penelitian ini adalah persebaran variabel independen yang sudah tersaji dalam bentuk peta kuantil tematik.

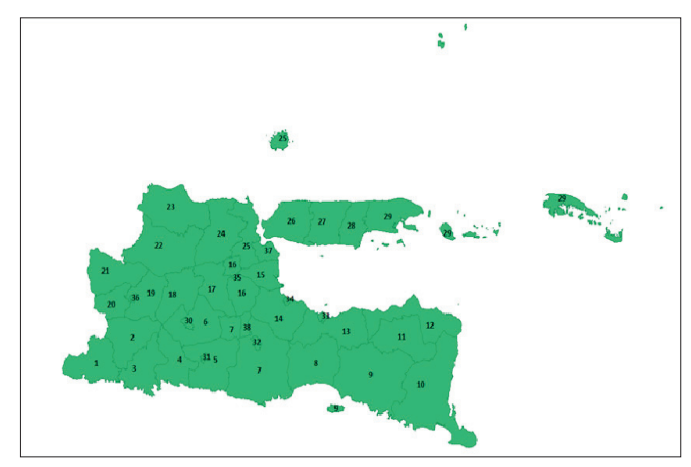

Gambar 1. Peta Kabupaten/Kota Provinsi Jawa Timur. 
Gambar 1 yaitu peta Provinsi Jawa Timur yang telah diberikan kode wilayah. Gambar tersebut menunjukkan jumlah wilayah Kabupaten/Kota di Provinsi Jawa Timur sebanyak 38 Kabupaten/Kota secara spasial, serta wilayah mana yang berbatasan secara langsung antara satu dengan yang lain.

Gambaran spasial atau menurut wilayah kuantil sebaran pneumonia pada balita di Provinsi Jawa Timur yang diperoleh dari hasil data sekunder menunjukkan hasil sebagai berikut:

Gambar 2 diketahui bahwa pneumonia di Jawa Timur tersebar merata. Gambar dengan warna gelap menunjukkan pada wilayah tersebut angka kejadian pneumonia pada balita tercatat cukup tinggi. sedangkan warna yang lebih cerah menunjukkan angka kejadian juga semakin kecil.

Jumlah kasus pneumonia paling banyak terdapat pada lima Kabupaten yaitu Kabupaten Bondowoso, Kabupaten Mojokerto, Kabupaten Bojonegoro, Kabupaten Gresik, dan Kabupaten Bangkalan. Selain itu kasus paling banyak juga terjadi di tiga Kota yaitu Kota Kediri, Kota Mojokerto, dan Kota Madiun.

Kasus pneumonia pada balita terendah terjadi di Kabupaten Pacitan, Kabupaten Malang, Kabupaten Pasuruan, Kabupaten Madiun, Kabupaten Ngawi, Kabupaten Sampang, Kabupaten Pamekasan, Kabupaten Sumenep, dan Kota Batu.

Faktor yang mempengaruhi resiko terjadinya pneumonia pada balita salah satu diantaranya yaitu imunisasi campak, pemberian vitamin A, PHBS, dan gizi buruk. Hasil sebaran faktor risiko pneumonia pada balita terutama di Provinsi

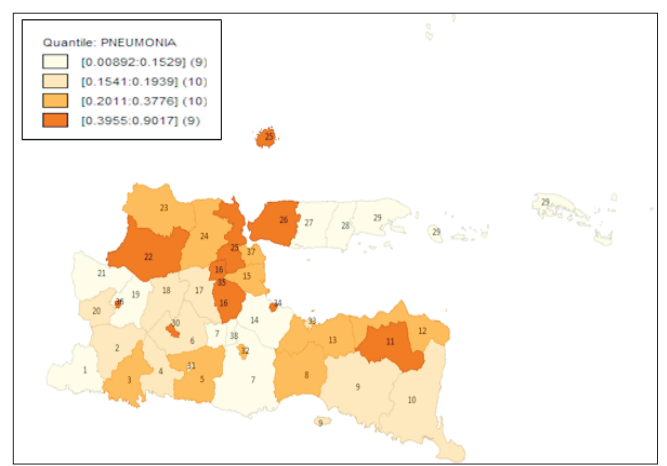

Gambar 2. Kuantil Sebaran Pneumonia pada Balita di Provinsi Jawa Timur.

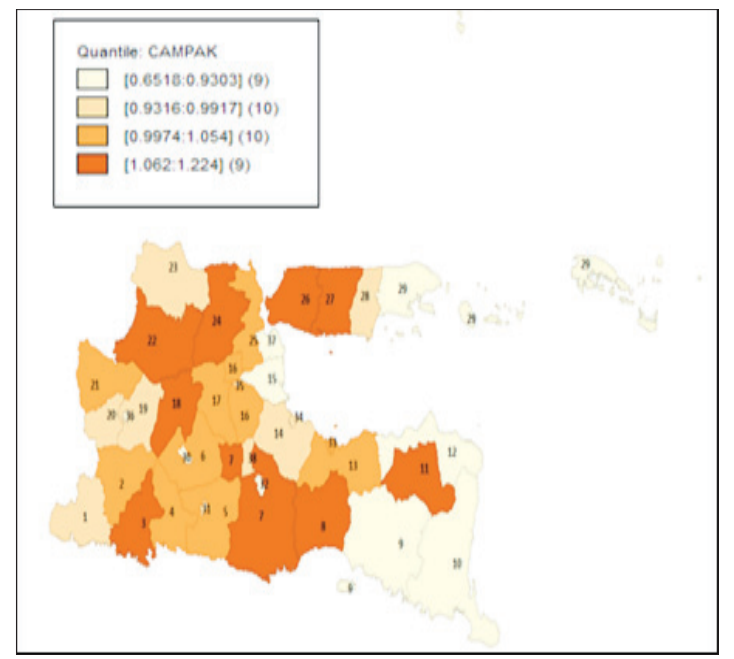

Gambar 3. Peta Kuantil Sebaran Imunisasi Campak di Provinsi Jawa Timur.

Jawa Timur pada penelitian ini yaitu gambar 3 menunjukkan sebaran imunisasi campak di Provinsi Jawa Timur. Cakupan imunisasi campak pada balita sedikit terdapat pada lima Kabupaten yaitu Kabupaten Jember, Kabupaten Banyuwangi, Kabupaten Situbondo, Kabupaten Sidoarjo, Kabupaten Sumenep. Selain itu juga terdapat di empat Kota yaitu Kota Surabaya, Kota Madiun, Kota Kediri, dan Kota Malang.

Hasil penelitian juga menunjukkan sebaran imunisasi campak di Provinsi Jawa Timur, angka tertinggi/kasus terbanyak terdapat di lima Kabupaten dan dua Kota. Kabupaten/Kota tersebut yaitu Kabupaten Jember, Kabupaten Banyuwangi, Kabupaten Situbondo, Kabupaten Sidoarjo, Kabupaten Sumenep, Kota Surabaya, Kota Madiun, dan Kota Malang.

Selain imunisasi campak pneumonia juga dapat dipengaruhi oleh vitamin A dan sebarannya dapat dilihat pada gambar 4 .

Gambar 4 menunjukkan sebaran cakupan vitamin A di Provinsi Jawa Timur menunjukkan cakupan terendah terdapat di delapan Kabupaten dan satu Kota yaitu Kabupaten Pacitan, Kabupaten Ponorogo, Kabupaten Tulungagung, Kabupaten Jember, Kota Kediri, Kabupaten Lamongan, Kabupaten Bangkalan, Kabupaten Sampang, dan Kabupaten Pamekasan.

Cakupan vitamin A di Provinsi Jawa Timur tertinggi terdapat di enam Kabupaten dan tiga Kota. Kabupaten/Kota tersebut yaitu Kabupaten 


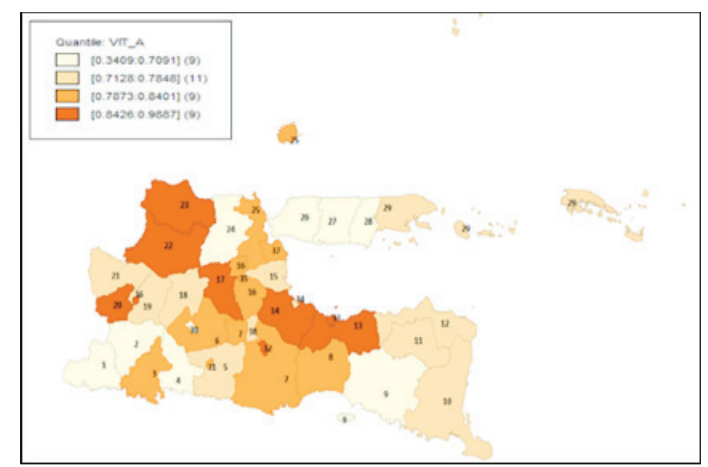

Gambar 4. Peta kuantil sebaran Cakupan vitamin A di Provinsi Jawa Timur.

Probolinggo, Kota Probolinggo, Kabupaten Pasuruan, Kota Malang, Kabupaten Jombang, Kabupaten Magetan, Kabupaten Bojonegoro, Kabupaten Tuban dan Kota Madiun.

Gambar 5 menunjukkan sebaran keluarga berperilaku hidup bersih dan sehat (berPHBS) di Provinsi Jawa Timur sudah hampir merata. Wilayah yang termasuk dalam kuantil terendah yaitu Kota Batu dan tujuh Kabupaten lain. Kabupaten tersebut yaitu Kabupaten Bondowoso, Kabupaten Situbondo, Kabupaten Probolinggo, Kabupaten Nganjuk, Kabupaten Bangkalan, Kabupaten Sampang, dan Kabupaten Pamekasan.

Gambar 6 menunjukkan sebaran gizi buruk di Provinsi Jawa Timur. masih terlihat di beberapa daerah Kabupaten dan Kota. Wilayah yang termasuk wilayah dalam jumlah tertinggi terdiri

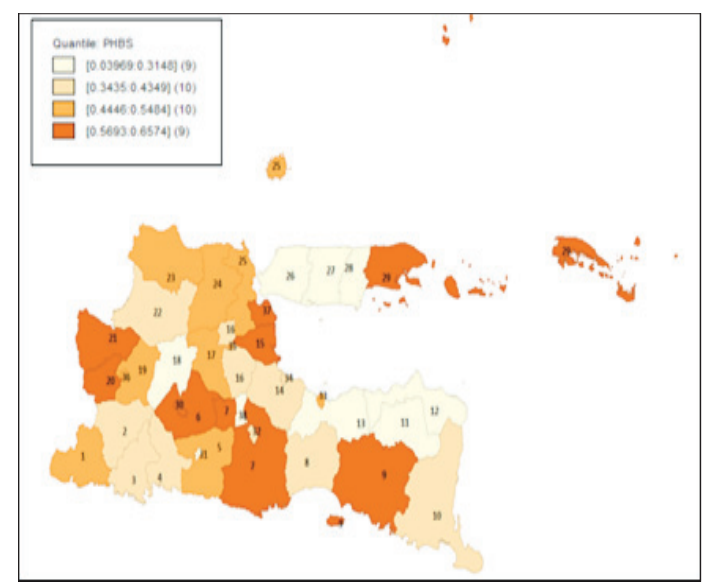

Gambar 5. Peta Kuantil Sebaran Keluarga BerPHBS.Di Provinsi Jawa Timur

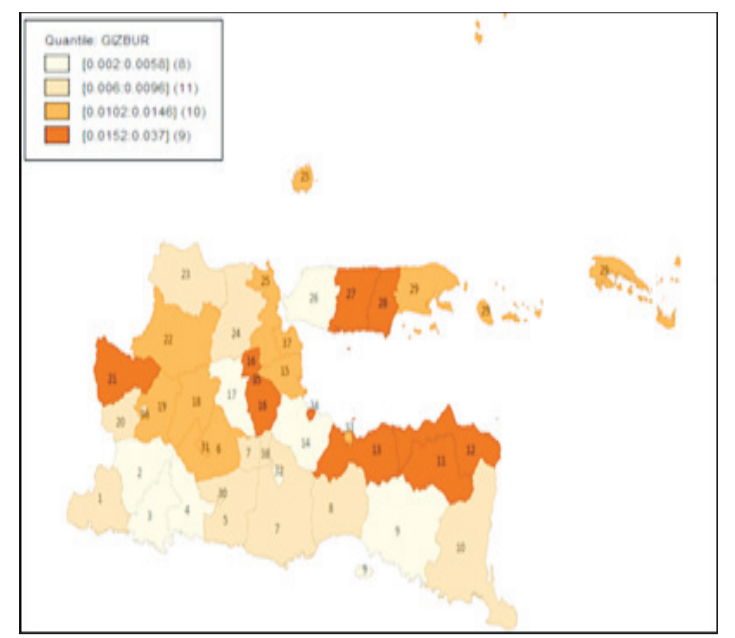

Gambar 6. Peta Kuantil Sebaran Gizi Buruk Di Provinsi Jawa Timur

dari tujuh wilayah Kabupaten dan empat Kota. Wilayah tersebut yaitu Kabupaten Bondowoso, Kabupaten Situbondo, Kabupaten Probolinggo, Kabupaten Mojokerto, Kabupaten Ngawi, Kabupaten Sampang, Kabupaten Pamekasan, Kota Pasuruan, dan Kota Mojokerto.

Sebaran gizi buruk dengan kuantil terendah terdapat pada tujuh Kabupaten dan satu Kota. Wilayah tersebut yaitu Kabupaten Ponorogo, Kabupaten Trenggalek, Kabupaten Tulungagung, Kabupaten Jember, Kabupaten Pasuruan, Kabupaten Jombang, Kabupaten Bangkalan, dan Kota Malang.

\section{PEMBAHASAN}

Pneumonia merupakan penyakit infeksi saluran pernapasan akut (ISPA) yang paling sering menyebabkan kematian pada bayi dan balita. Penyakit ini merupakan penyakit infeksi yang ditandai dengan batuk pilek yang disertai sesak nafas atau frekuensi nafas yang menjadi lebih cepat. Penyakit ini dapat menyerang segala usia, akan tetapi lebih sering menyerang pada usia balita.

Pada penelitian ini dapat diketahui bagaimana persebaran penyakit pneumonia pada balita di Provinsi Jawa Timur. Faktor yang dapat mempengaruhi terjadinya pneumonia pada balita, data tersebut juga diolah, sehingga dapat diketahui faktor mana yang memungkinkan menjadi faktor yang mempengaruhi kasus tersebut. 
Pemetaan suatu penyakit di wilayah tertentu sangat diperlukan. Kegiatan pendokumentasian yang telah terekam di olah dalam bentuk data grafis. Sehingga situasi yang ada lebih mudah terbaca dan penanganannya dapat disesuaikan dengan kondisi pada masing-masing wilayah.

Pemetaan pada kasus pneumonia ini akan menunjukkan bagaimana konsisi kasus pneumonia. Wilayah yang rawan terhadap kasus ini akan dapat diketahui beserta data faktor yang dapat mempengaruhi persebarannya.

Berdasar hasil penelitian, diketahui bahwa penyakit pneumonia pada balita di Provinsi Jawa Timur pada Tahun 2012 hampir tersebar secara merata. Secara spasial dapat diketahui letak Kabupaten/Kota dengan kasus terbanyak hampir terletak secara berdekatan.

Tingginya kasus pneumonia pada setiap wilayah berbeda-beda antara satu dengan yang lain. Faktor yang mempengaruhi pada setiap daerah juga berbeda pula.

Pneumonia merupakan salah satu penyakit yang berbahaya karena bila tidak mendapat perawatan dengan benar, maka akan dapat menyebabkan kematian Penderita penyakit ini dapat terjadi pada semua usia. Selain itu faktor utama yang menjadi penyebab pneumonia pun belum diketahui secara pasti. Pengobatan yang salah pada penderita penyakit ini, justru dapat menjadi penyebab kematian pada pasien.

Sebagian besar masyarakat tidak mengetahui tanda dari penyakit pneumonia. Balita yang menderita pneumonia, sebagian besar orang tua mereka juga tidak paham. Sehingga pengobatan yang diberikan hanya seadanya saja. Gejala dari penyakit ini sering dianggap hanya penyakit flu biasa dan beberapa hari kemudian akan sembuh dengan sendirinya. Hal ini lah, yang menjadikan penanganan pneumonoia menjadi terlambat. Dampak dari keterlambatan pengobatan ini yaitu penyakit menjadi lebih parah sehingga bahaya kematian pun menjadi ancaman dan dapat terjadi.

Gejala pneumonia yang kurang dimengerti tidak hanya berakibat pada penanganan yang seharusnya diberikan dengan segera. Pencatatan dan pelaporan kasus pneumonia pada sarana pelayanan kesehatan pun menjadi tidak akurat. Besarnya kasus yang terlaporkan dengan kondisi di masyarakat juga menjadi berbeda.
Kondisi geografis pada masing-masing wilayah, kebiasaan budaya atau tradisi tiap daerah juga sangat berpengaruh pada kasus pneumonia. Wilayah yang terpencil dan jauh dari sarana pelayanan kesehatan juga dapat menjadi faktor penting dalam memperoleh penanganan yang tepat. Kondisi lingkungan di sekitar balita juga berpengaruh. Pada wilayah perkotaan kondisi/letak rumah relatif berdekatan dan kurang sehat. Jumlah penghuni pun juga lebih banyak tidak sebanding dengan kondisi rumah. Kondisi rumah yang lembab, kurangnya baiknya sirkulasi udara, dan kebiasaan penghuni juga sangat berpengaruh.

Pada wilayah pedesaan kondisi rumah relatif lebih jauh sehingga kondisi rumah lebih baik dan sehat. Tetapi di wilayah pedesaan juga dapat memengaruhi terjadinya pneumonia. Hal ini disebabkan di desa sebagian masih ada rumah yang berlantai tanah. Sehingga menjadi lebih lembab, terdapatnya kandang ternak yang mungkin berdekatan dengan rumah, kondisi dapur yang masih menggunakan kayu bakar, dan pengolahan sampah yang masih dilakukan dengan cara dibakar.

Letak suatu wilayah yang berbatasan relatif memiliki kondisi geografis dan budaya/kebiasaan yang tidak terlalu jauh berbeda antara satu dengan yang lain. Kondisi ini juga memungkinkan besarnya kasus pneumonia hampir sama. Wilayah yang mempunyai letak geografis berdekatan akan mempunyai pengaruh satu sama lain.

Pada penelitian ini telah dilakukan pemetaan kondisi kasus pneumonia pada balita. faktor yang kemungkinan dapat menjadi risiko pun juga dilakukan pengolahan data dalam bentuk spasial. Sehingga kasus yang terjadi dan kondisi faktor yang dapat menjadi penyebab juga dapat diketahui.

Selain itu pengolahan data ini juga akan memudahkan pengawasan. Sehingga penanganan yang diberikan akan jauh lebih tepat sesuai dengan penyebab masing-masing wilayah.

Sebaran imunisasi campak di beberapa Kabupaten/Kota di Provinsi Jawa Timur menduduki kuantil ke empat/jumlah balita yang melakukan imunisasi sedikit. Wilayah yang memiliki cakupan imunisasi rendah beberapa justru di wilayah perkotaan. 
Hasil penelitian menunjukkan Kota Kediri dan Kota Madiun sebaran pneumonia pada balita menunjukkan kuantil ke empat atau jumlah kasus nya sedikit. Pada sebaran imunisasi campak kedua wilayah tersebut memiliki cakupan imunisasi campak yang juga rendah. Sehingga kemungkinan penyebab dari tingginya pneumonia di wilayah tersebut disebabkan karena imunisasi campak yang kurang terpenuhi. Pneumonia merupakan salah satu komplikasi yang disebabkan oleh penyakit infeksi yang disebut campak. Penyakit campak yang masih ringan dapat sembuh sendiri. Pada kasus yang berat, penyakit ini dapat menyebabkan komplikasi seperti pneumonia bahkan paling berat dapat menyebabkan kematian. Angka kejadian pneumonia secara tidak langsung akan turun dengan pemberian imunisasi campak.

Imunisasi akan memberikan pengaruh pada kelangsungan hidup anak. Semakin meningkat imunisasi yang diperoleh maka akan semakin meningkat pula kelangsungan hidup anak. Sehingga semakin terpenuhinya cakupan imunisasi, maka kelangsungan hidup anak akan dapat ditingkatkan (Bappenas, 2009).

Cakupan pemberian vitamin A di Jawa Timur pada tahun 2012 kuantil terendah berada di daerah pulau Madura dan wilayah pesisir pantai selatan. Salah satu wilayah tersebut yaitu Kota Kediri dan Kabupaten Bangkalan. Rendahnya cakupan ini bisa menjadi faktor tinggi nya angka pneumonia di wilayah tersebut.

Hal ini terbukti dengan hasil penelitian, sebaran pneumonia di kabupaten Bangkalan termasuk dalam kelompok lima kelompok wilayah kuantil tertinggi/jumlah kasus terbanyak. Sedangkan di Kota Kediri kasus pneumonia pada balita masih termasuk dalam kuantil terendah/ jumlah kasus sedikit.

Vitamin A merupakan zat gizi yang penting karena dapat meningkatkan daya tahan tubuh. Menurut Fitriyah (2013), kebutuhan vitamin A yang terpenuhi dengan baik maka akan mengurangi risiko terjadinya penyakit infeksi.

Kondisi tetap tingginya kasus pneumonia walaupun cakupan pemberian vitamin A sudah cukup baik dapat terjadi karena beberapa kemungkinan diantaranya yaitu vitamin A yang diberikan tidak sesuai aturan pemberian, baik dari segi dosis, masa kedaluwarsa, teknik penyimpanan atau interaksi obat sehingga walaupun persentase balita mendapat vitamin A tinggi namun tidak mampu meningkatkan imunitas balita. Kemungkinan lainnya juga bisa disebabkan persentase pemberian vitamin A pada balita tinggi namun tidak mencapai target cakupan (Sofia, 2014).

Keluarga yang ber-PHBS di Jawa Timur tidak tersebar merata. Kuantil terendah terlihat pada daerah tapal kuda yaitu Kabupaten Bondowoso, Kabupaten Situbondo, dan Kabupaten Probolinggo yang mayoritas adalah etnik Madura. Sebagian besar di Provinsi Jawa Timur angka keluarga ber-PHBS sudah meningkat, akan tetapi masalah yang masih perlu dihadapi yaitu perilaku merokok dan pemberian ASI eksklusif.

Perilaku kesehatan lingkungan (environment health behavior) tidak sehat yang dilakukan ibu balita dan memiliki risiko terjadinya pneumonia, meliputi perilaku tidak membuka jendela kamar tidur setiap hari, perilaku merokok di dalam rumah, perilaku ada penghuni yang merokok di dalam rumah, perilaku ibu menggantung baju dan menyimpan buku dalam kamar tidur, tidak menjauhkan anak dari orang yang sedang merokok, tidak membuka jendela ruang keluarga, serta perilaku membakar sampah di sekitar rumah. Seluruh perilaku tidak sehat tersebut akan berakibat pencemaran udara di dalam dan di luar rumah, sehingga kualitas udara pernapasan tidak memenuhi syarat yang pada akhirnya akan berpengaruh terhadap terjadinya pneumonia pada balita. (Sundari, 2014).

Menurut Shibata, et al (2014), orang tua yang mempunyai kebiasaan merokok dapat menjadi salah satu faktor risiko dapat terjadinya gangguan kesehatan terutama pernapasan. Hal ini dapat disebabkan karena anak-anak terutama pada usia balita akan lebih sering berkumpul bersama keluarga. Walaupun orang tua atau keluarga tidak merokok di depan balita, asap rokok yang telah menempel di pakaian masih bisa masuk ke dalam sistem pernapasan.

Pemberian ASI eksklusif pada balita masih menjadi masalah yang perlu ditangani. Faktor ekonomi dapat menjadi salah satu penyebab belum tercapainya ASI eksklusif. Banyak Ibu harus pergi bekerja demi terpenuhinya kebutuhan keluarga. Sehingga proses pemberian 
ASI tidak dapat terlaksana secara eksklusif. Ibu yang bekerja seringkali terhambat dalam proses pemberian ASI, karena pada saat proses persalinan waktu cuti yang diperoleh cukup singkat, tidak ada nya tempat pojok laktasi, dukungan keluarga juga masih kurang, dan kurangnya pengertian dan pengetahuan ibu tentang bagaimana cara penyimpanan ASI yang telah diperah.

Ibu yang tidak harus pergi bekerja pun masih banyak yang belum dapat memberikan ASI eksklusif karena kurang nya pemahaman dan dukungan dari pihak keluarga, serta karena semakin banyaknya promosi susu formula.

Kandungan gizi dalam ASI sangat penting untuk pertumbuhan bayi. Selama bayi masih dalam kandungan antibody akan diperoleh dari tubuh ibu. Setelah lahir, bayi tidak mendapatkan antibody seperti sebelumnya dan kekebalan bayi pun masih belum sempurna seperti orang dewasa. Oleh sebab itu bayi lebih berisiko terserang penyakit. Dengan pemberian ASI, bayi akan memperoleh antibody kembali yang terkandung didalamnya. Sehingga diharapkan dengan pemberian ASI eksklusif dapat menekan terjadinya penyakit infeksi terutama pneumonia.

Sebaran status gizi buruk terlihat sedikit mengelompok. Wilayah dengan kuantil tertinggi/ kasus terbanyak terdapat pada pulau Madura (Kabupaten Sampang dan Kabupaten Pamekasan) dan daerah tapal kuda serta Kabupaten/Kota lain.

Penyakit ISPA terutama pneumonia sering terjadi pada anak balita, karena sistem pertahanan tubuh anak masih rendah. Kejadian batuk pilek pada balita di Indonesia diperkirakan 3 sampai 6 kali pertahun, yang berarti seorang balita ratarata mendapat serangan batuk pilek 3 sampai 6 kali setahun. Penyakit ISPA dapat ditularkan melalui ludah, bersin, udara pernapasan yang mengandung kuman yang terhirup oleh orang sehat ke saluran pernapasannya. Infeksi saluran pernapasan bagian atas terutama yang disebabkan oleh virus, sering terjadi pada semua golongan umur, tetapi ISPA yang berlanjut menjadi Pneumoni sering terjadi pada anak kecil terutama apabila terdapat gizi kurang dan dikombinasi dengan keadaan lingkungan yang tidak bersih (Sundari, 2014).
Nutrisi merupakan elemen penting untuk proses dan fungsi tubuh. Fungsi nutrisi yaitu menjaga keseimbangan daya tahan tubuh. Jika kondisi tubuh mengalami kekurangan gizi maka jumlah limfosit mengalami penurunan. Sehingga imunitas seluler akan rusak dan terganggu (Brunner \& Suddarth, 2004).

Balita yang mengalami gizi buruk maka proses pertumbuhannya akan terganggu bukan hanya secara fisik tetapi juga secara mental. Akibat dari kurangnya pemenuhan gizi ini bukan hanya terjadi pada saat masa anak-anak. Gangguan pertumbuhan ini akan berakibat sampai anak tumbuh dewasa. (Kendala et al., 2011).

Keadaan gizi yang buruk muncul sebagai faktor terjadinya penyakit infeksi. Kekebalan tubuh akan menjadi turun yang berarti kemampuan tubuh mempertahankan diri terhadap infeksi menjadi turun. Oleh karena itu setiap bentuk gangguan gizi sekalipun dengan gejala defisiensi yang ringan merupakan pertanda awal dari terganggunya kekebalan tubuh terhadap penyakit infeksi (WHO, 2013).

Balita merupakan usia yang masih sangat memerlukan perhatian dan perawatan yang baik dari orang tua dan keluarga. Kondisi imun pada bayi sangat dipengaruhi oleh nutrisi terutama yang berasal dari ASI. Bayi yang mendapat ASI eksklusif maka nutrisinya akan terpenuhi dan sesuai dengan kebutuhannya. Sehingga risiko gizi buruk pun akan dapat berkurang. Pada usia diatas 6 bulan maka bayi akan memerlukan tambahan nutrisi dari makanan yang sehat. Imunisasi pun juga sangat diperlukan oleh bayi dan balita untuk menambah kekebalan tubuhnya yang tidak diperoleh dari ASI. Faktor imunisasi, ASI, gizi buruk, dan PHBS sangat berhubungan antara satu dengan yang lain. Bila faktor tersebut ditangani dengan baik maka risiko pneumonia pun akan dapat dicegah.

\section{SIMPULAN DAN SARAN}

\section{Simpulan}

Pada penelitian ini yaitu pemetaan Pneumonia pada balita di Provinsi Jawa Timur. Wilayah dengan kasus terbanyak terdapat di lima Kabupaten dan tiga Kota. Wilayah Kabupaten tersebut yaitu Kabupaten Bondowoso, Kabupaten 
Mojokerto, Kabupaten Bojonegoro, Kabupaten Gresik, dan Kabupaten Bangkalan. Selain itu tiga Kota yang juga termasuk kuantil tertinggi atau wilayah dengan kasus terbanyak yaitu Kota Kediri, Kota Mojokerto, dan Kota Madiun. Wilayah dengan kasus pneumonia terbanyak mayoritas wilayah tersebut secara spasial relatif berdekatan antara wilayah satu dengan lainnya.

\section{Saran}

Wilayah yang rawan akan terjadinya kasus pneumonia diharapkan menjadi perhatian bagi pemerintah selain itu juga masyarakat di wilayah tersebut. Faktor yang dapat mempengaruhi tingginya kasus juga harus lebih diperbaiki. Sehingga kasus dapat berkurang. Pencegahan pneumonia dapat dimulai dari lingkup keluarga. Penyuluhan terhadap orang tua sangat diperlukan, terutama akan pentingnya Imunisasi yang lengkap, gizi yang baik, dan bahayanya perilaku merokok.

\section{DAFTAR PUSTAKA}

Achmadi, U.F. 2009. Manajemen Penyakit Berbasis Wilayah. Jurnal Kesehatan Masyarakat Nasional Vol. 3 No. 4: 147-153.

Badan Perencanaan Pembangunan Nasional (BAPPENAS). 2009. Faktor-faktor yang Memengaruhi Kelangsungan Hidup Anak. Jakarta: Kadeputian Evaluasi Kinerja Pembangunan Badan Perencanaan Pembangunan Nasional.

Badan Pusat Statistik. 2013. Laporan Eksekutif Kesehatan Provinsi Jawa Timur 2012. Surabaya: Badan Pusat Statistik Provinsi Jawa Timur.

Brunner., Suddarth. 2004. Buku Ajar Keperawatan Medikal Bedah. Jakarta: EGC.

Depkes, RI. Profil Kesehatan Indonesia 2009. Jakarta: Depkes RI, 2010.

Depkes, RI. Pneumonia penyebab kematian Depkes RI; 2011. Dari: www.depkes.go.id [29 Agustus 2015]

Fitriyah, Riska. 2013. Hubungan Asupan dan Pola Konsumsi Vitamin A, Protein dan Zinc dengan Kejadian ISPA dan Status Gizi pada Anak. Skripsi. Surabaya: Fakultas Kesehatan Masyarakat Universitas Airlangga.
Handayani, L.T. 2013.Regresi Spatial pada Kematian Ibu di Kabupaten Jember. Tesis. Surabaya: Universitas Airlangga.

Indriasih, E. 2008. Sistem Informasi Geografis (SIG) dalam Bidang.

Kesehatan Masyarakat. Bulletin Penelitian Sistem Kesehatan. Surabaya: Airlangga Univercity Press: 18-21.

Kandala et al. 2011. Malnutrition among children under the age of five in the Democratic Republic of Congo (DRC): does geographic location matter?. International Journal of BMC Public Health. 10.1186/1471-2458-11261.

Lisnawati, N.P. 2013. Pemodelan dan Pemetaan Faktor yang Memengaruhi Jumlah Kasus AIDS Tahun 2010 Provinsi Jawa Timur. Skripsi. Surabaya; Fakultas Kesehatan Masyarakat Universitas Airlangga.

Maulana, Heri D.J. 2009. Promosi Kesehatan. Jakarta: EGC.

Misnadiarly. 2008. Penyakit Infeksi Saluran Pernafasan Pneumonia pada Anak Balita, Orang Dewasa, Usia Lanjut. Jakarta: Pustaka obor popular.

Prahasta. E. 2005. Sistem Informasi Geografis. Bandung; CV Informatika.

Shibata, Tomayuki, Wilton, J.L., Watson, L.M., et al. 2014. Childhood Acute Respiratory Infections and Household Environment in an Eastern Indonesian Urban Setting. International Journal of Environmental Research and Public Health Vol. 11 page: 12190-12203.

Sundari, Siti. 2014. Perilaku Tidak Sehat Ibu yang Menjadi Faktor Risiko Terjadinya ISPA Pnrumonia pada Balita. Jurnal Pendidikan Sains, vol. 2 no. 3: 141-147.

Susanti, Sulis. 2015. Analisis Spasial Faktor Pneumonia pada Balita di Provinsi Jawa Timur. Skripsi. Surabaya; Fakultas Kesehatan Masyarakat Universitas Airlangga.

Sofia, Debbiyatus. 2014. Pemodelan Bayesian Model Averaging (BMA) pada Kasus Pneumonia Balita. Jurnal Biometrika dan Kependudukan, vol. 3 No. 1: 34-42.

WHO. 2013. World Health Statistic 2013. Perancis: 82-84. 